NBER WORKING PAPER SERIES

\title{
DIVIDEND TAXES AND SHARE PRICES: EVIDENCE FROM REAL ESTATE INVESTMENT TRUSTS
}

\author{
William M. Gentry \\ Deen Kemsley \\ Christopher J. Mayer \\ Working Paper 8486 \\ http://www.nber.org/papers/w8486 \\ NATIONAL BUREAU OF ECONOMIC RESEARCH \\ 1050 Massachusetts Avenue \\ Cambridge, MA 02138 \\ September 2001
}

\begin{abstract}
We thank Mary Ellen Carter, Rick Green, David Guenther, Charlie Himmelberg, Laurie Hodrick, Glenn Hubbard, Charles Jones, Doron Nissim, Matt Rhodes-Kropf, Raghu Rau, Lynne Sagalyn, Todd Sinai, Nick Souleles, an anonymous referee, and seminar participants at Columbia Business School, the National Bureau of Economic Research, Stanford University, the University of California at Berkeley, the University of North Carolina Tax Symposium, the Western Finance Association meetings, and The Wharton School for helpful comments. Geoffrey Jervis provided excellent research assistance. We also express our great appreciation to Jon Fosheim and Green Street Advisors, Inc. for providing data, and to the Columbia Business School Real Estate Program for funding. The views expressed herein are those of the author(s) and not necessarily those of the National Bureau of Economic Research.
\end{abstract}

(C) 2001 by William M. Gentry, Deen Kemsley and Christopher J. Mayer. All rights reserved. Short sections of text, not to exceed two paragraphs, may be quoted without explicit permission provided that full credit, including (C) notice, is given to the source. 
Dividend Taxes and Share Prices: Evidence from Real Estate Investment Trusts William M. Gentry, Deen Kemsley and Christopher J. Mayer

NBER Working Paper No. 8486

September 2001

JEL No. H25, G32, G12

\begin{abstract}
$\underline{\text { ABSTRACT }}$
Financial economists have debated the impact of dividend taxes on firm valuation for decades, but existing empirical evidence is mixed. In this study, we avoid certain complications inherent in previous empirical work by exploiting institutional characteristics of Real Estate Investment Trusts (REITs). For REITs, dividend policy is largely non-discretionary, share repurchases are not tax advantaged relative to dividends, and the market value of a firm's assets is relatively transparent to investors. In addition, REITs are exempt from corporate taxes, so their tax deductions flow directly to shareholders as reductions in dividend taxes. Within this environment, we regress the market value of a REIT's equity on the market value of its assets and its tax basis in assets, which creates tax deductions that lower future dividend taxes. We find that tax basis has a positive effect on firm value, which suggests that investors capitalize future dividend taxes into share prices.
\end{abstract}

$\begin{array}{lll}\text { William M. Gentry } & \text { Deen Kemsley } & \text { Christopher J. Mayer } \\ \text { Graduate School of Business } & \text { Graduate School of Business } & \text { The Wharton School } \\ \text { Columbia University } & \text { Columbia University } & \text { University of Pennsylvania } \\ \text { 602 Uris Hall } & \text { 607 Uris Hall } & \text { 314 Lauder-Fischer Hall } \\ \text { 3022 Broadway } & \text { 3022 Broadway } & \text { 256 South 37 } \\ \text { New Ytreet } \\ \text { and NBER NY } 10027 & \text { New York, NY 10027 } & \text { Philadelphia, PA 19104 } \\ \text { Tel: } 212-854-5092 & \text { Tel: 212-854-2641 } & \text { Tel: 215-573-5009 } \\ \text { Fax: } 212-316-9219 & \text { Fax: 212-316-9219 } & \text { Fax: 215-573-2220 } \\ \text { wmg6@columbia.edu } & \text { dk151@columbia.edu } & \text { mayerc@wharton.upenn.edu }\end{array}$




\section{Dividend Taxes and Share Prices:}

\section{Evidence from Real Estate Investment Trusts}

Financial economists have debated the impact of dividend taxes on firm valuation and the cost of equity capital for decades. In 1970, Brennan proposed that investors should impose a price penalty on the shares of high-dividend firms because capital gains are tax-preferred relative to dividends. In 1978, Miller and Scholes countered that prices may not reflect shareholder taxes at all because the marginal investor could be a tax-exempt institution. Simultaneously, Auerbach (1979), Bradford (1981), and King (1977) posited that dividend taxes should be capitalized into share prices for all firms that will eventually distribute earnings through dividends, not just for firms that pay current dividends. Theoretically, all three arguments have potential strengths and weaknesses, so empirical investigation is required.

Empirical investigation of the share price effects of dividend taxes has followed two primary lines of inquiry. First, studies use long event windows to examine the hypothesis that dividend taxes increase pretax returns, which would indicate they also affect prices. ${ }^{1}$ Despite extensive research in this area, no consensus has emerged, largely because it has proven difficult to control for the nontax determinants of returns (e.g., risk). Second, researchers use exdividend-day share price behavior to examine the hypothesis that pretax returns increase in

${ }^{1}$ Litzenberger and Ramaswamy (1979, 1982), Rosenberg and Marathe (1979), and Blume (1980) are among the studies supporting a positive relation between pretax returns and dividends, while Black and Scholes (1974), Gordon and Bradford (1980), Miller and Scholes (1982), and Fama and French (1993) do not find this relationship. Chen, Grundy, and Stambaugh (1990) argue that risk contributes to the alleged tax effects. While Naranjo, Nimalendran, and Ryngaert (1998) find a positive relation between returns and dividend yields, they claim that the positive relation is too large to be a pure tax effect and show that it is unrelated to changes in tax rates over time. 
dividends because taxes result in less-than-dollar-for-dollar declines in share prices on exdividend days. Despite numerous studies supporting this hypothesis, several questions persist about the results. ${ }^{2}$ For example, arbitrage trading could offset price reactions (see, e.g., Kalay, 1982, Karpoff and Walkling, 1988, and Naranjo, Nimalendran, and Ryngaert, 2000), discreteness in trading prices could lead to spurious results (Bali and Hite, 1998), or other nontax factors could influence ex-dividend day share price movements (see, e.g., Frank and Jagannathan, 1998).

Given the mixed prior evidence, Fama and French (1998) adopt a cross-sectional approach, focusing on prices rather than on returns. They regress the market value of firm equity on dividends and controls for expected future profitability. This regression is scaled by the book value of assets, which serves as a proxy for the market value of assets. Fama and French hypothesize that if investors impose a tax penalty on the prices of high-dividend firms, the coefficient on dividends should be negative. Instead, they find a positive coefficient on dividends, expressing concern that imperfect controls for future profitability and the market value of assets may cause the signaling attributes of dividends to obscure tax effects. Indeed, the information content of dividends potentially confounds interpretation of any study that uses dividend policy to examine tax effects.

In this study, we examine the share price effects of dividend taxes by focusing on Real Estate Investment Trusts (REITs). REITs are exempt from corporate income taxes but must limit their activities to owning and managing portfolios of real estate assets and pay out the bulk of their taxable income as dividends. These institutional features of REITs allow us to overcome

${ }^{2}$ For support, see Elton and Gruber (1970), Poterba and Summers (1984), Barclay (1987), Lamdin and Hiemstra (1993), and Green and Rydqvist (1999), among others. 
some of the obstacles that complicate previous studies of dividend taxes and share prices.

Given the relatively straightforward nature of REITs, for example, analysts typically evaluate REITs by estimating the value of their properties. These estimates allow us to control for the fair market value of assets. In addition, tax rules significantly restrict the activities REITs can undertake, so management has less impact on the value of a REIT than it has for typical industrial corporations. Therefore the market value of properties should capture much of a REIT's value, but not potential tax effects. Our empirical work exploits this feature by testing whether the difference between the market value of a firm's properties and its equity value depends on firm-level tax characteristics. We attempt to control for other nontax factors that also affect value.

Tax law also requires REITs to pay out most of their taxable income as dividends each year, so their dividend policy is less discretionary than that of other corporations, which allows us to largely sidestep dividend signaling issues. The dividend distribution requirement also implies that share repurchases are not viable substitutes for REIT dividends. For other firms, the tax advantages of share repurchases cloud predictions regarding the valuation of dividend taxes (see, e.g., Green and Hollifield, 2001).

Finally, REITs are generally exempt from corporate income taxes. Rather than reducing corporate taxes, REIT tax deductions pass straight through to shareholders by reducing the taxable component of dividends. Many of the tax deductions are from REITs' tax basis in properties because tax basis provides depreciation tax shields and offsets taxable gains when they sell properties. Therefore, we examine the hypothesis that, holding the market value of assets constant, firm value increases in the amount of tax basis REITs have in their assets. Given the 
pass-through nature of REITs, finding that investors value the inside tax basis of REIT assets is essentially equivalent to finding investors price shareholder-level dividend taxes. ${ }^{3}$

Empirically, we examine the price effects of REITs' tax basis in their assets for a sample of 393 observations (85 firms) from 1992 to 1999 . We test for dividend tax capitalization by regressing the market value of a REIT on the market value of its assets and the book value of its assets, which serves as a proxy for its tax basis in its assets. We find that investors assign a positive value to tax basis. In particular, we estimate that each dollar of tax basis is associated with an additional 9 to 27 cents of firm value, depending on our empirical specification, with most estimates ranging from 9 to 20 cents. Because these estimates reflect the present value of future depreciation (and other) tax benefits from tax basis, they imply that REIT prices appear to capitalize dividend taxes at high tax rates. This finding is consistent with a tax interpretation for the ex-dividend day evidence, and serves as a benchmark for assessing the impact of dividend taxes on share prices in more general settings, in which corporate taxes are assessed, dividend policy is more discretionary, and firms can use tax-favored share repurchases in lieu of taxable dividends.

The remainder of the paper proceeds as follows. In section I, we discuss REIT tax factors. In section II, we present a simple valuation model with taxes. Section III discusses our data and empirical methodology and section IV presents our empirical results. Section V concludes by discussing the implications and limitations of our results.

${ }^{3}$ Using event-study methodology, previous research (e.g., Cutler, 1988, and Givoly and Hayn, 1991) finds that share prices reflect the corporate tax benefits of depreciation. Because REITs do not pay corporate taxes, however, finding that investors value inside tax basis for REITs would provide evidence that share prices are a function of shareholder-level taxes in addition to entity-level taxes. 


\section{REIT Tax Factors}

With certain key exceptions, REITs are similar to other corporations. Like other corporations, for example, REITs often initiate operations by raising capital from external markets and investing the capital in operating assets. Although some REITs invest in real estate mortgages, we focus on equity REITs, which primarily invest in rental properties. For each property acquired, the REIT's initial tax basis is based on the original purchase price. Tax depreciation on the structure reduces the remaining tax basis of each property, just as book depreciation reduces the remaining book value of properties for financial reporting purposes. ${ }^{4}$ As for other corporations, tax depreciation may vary from book depreciation, but REITs generally use straight-line depreciation for both book and tax purposes.

The depreciation expense REITs claim each year reduces taxable income, and capital gains on the sale of assets increase taxable income. Unlike regular corporations, however, REITs receive an annual tax deduction for dividends paid out to shareholders. These dividends retain their character as ordinary income or capital gains in the hands of shareholders, and for our sample period, REITs only qualify for the dividend deduction if they distribute at least 95 percent of their taxable income to shareholders. ${ }^{5}$ As a practical matter, REITs often distribute all of their taxable income to shareholders each year, which eliminates the corporate tax altogether.

By reducing taxable income, depreciation decreases the amount of taxable dividends REITs must pass out to shareholders. However, depreciation does not reduce cash flow, so

\footnotetext{
${ }^{4}$ Note that an owner is able to depreciate the structure, but not the land for any real estate owned.

${ }^{5}$ See Brueggeman and Fisher (1997) for a list of REIT tax rules. The REIT Modernization Act of 1999 relaxed some restrictions. Beginning in 2001, the distribution requirement is only 90 percent of income and REITs can own taxable subsidiaries that conduct some previously-prohibited activities.
} 
operating cash flow typically exceeds taxable income. Therefore REIT managers make annual decisions to either reinvest the excess cash flow in improvements, new properties, or other assets, or to distribute the excess cash as tax-free return-of-capital dividends to shareholders. In our sample, approximately half of the REITs made at least some voluntary tax-free return-of-capital distributions to shareholders at least once during our sample period, tax-free distributions account for 23 percent of total distributions, and there is a positive correlation between depreciation expense and tax-free return-of-capital distributions. ${ }^{6}$ Occasionally, REITs use excess cash flow to repurchase shares. Given the option to distribute the excess cash flow as taxfree dividends, however, share repurchases do not offer the tax advantages for REITs that they provide for regular corporations.

Over the life of a real estate property, tax depreciation is likely to exceed the true economic depreciation of the property, which creates a wedge between tax basis and market value. Indeed, growth in demand often causes a property to appreciate in value, despite the tax depreciation deductions recognized. Eventually, the REIT may exchange or sell the property. According to current tax rules, if the REIT exchanges the property for another property in a qualified transaction, no capital gain is recognized, and the remaining tax basis in the original property is transferred to the new property for continued depreciation. If the REIT sells the property, it recognizes a taxable capital gain that it must pass out to shareholders. Any remaining tax basis in the property, including any basis in land, reduces the taxable gain. Over the life of the property, therefore, the REIT's tax basis in the property reduces taxable income for

\footnotetext{
${ }^{6}$ Specifically, the correlation between depreciation expense (scaled by the book value of assets) and the percentage of total distributions that represent nontaxable returns of capital is 0.18 (with a pvalue of 0.001).
} 
shareholders by (a) reducing the taxable component of annual distributions (through depreciation deductions), and/or (b) reducing the taxable capital gain upon sale of the property. In the next section, we model the potential valuation effects of these benefits derived from tax basis.

\section{Valuation Model}

We begin by assuming the market value of equity (MVE) equals the market value of assets (MVA) less the market value of debt (D) plus all other factors influencing MVE $(\mu)$ as follows:

$$
\text { MVE }=\text { MVA }-D+\mu
$$

Our primary objective is to specify how shareholder taxes affect the relationship between the MVE and MVA. That is, we consider how taxes affect the value of owning equity in an existing REIT relative to owning the assets directly as a new owner.

In our empirical work, MVA reflects property appraisals that represent the fair market values of comparable properties. Thus, MVA represents the market prices outside investors would be willing to pay for the firm's assets. These comparable prices would incorporate any general equilibrium effects of taxes on asset prices. If an outside investor purchased all of the REIT's properties for their market value of MVA, the buyer's tax basis in the assets (TB) would equal MVA, or TB = MVA. That is, the outside investor would have full tax basis in the properties to generate depreciation tax deductions or to reduce future taxable gains on the eventual sales of the properties.

In contrast to outside investors, REITs typically do not have full tax basis in their 
properties because they already have exhausted some of the depreciation tax deductions from the properties, and because property values may have changed since their purchase dates. To the extent TB is less than MVA, REITs face greater future tax liabilities on earnings from their properties than outside investors would face. ${ }^{7}$ REITs pass out the additional tax liabilities to shareholders through taxable ordinary dividends or occasionally through taxable capital gain dividends. Given that MVA reflects the market value of assets for outside investors, the after-tax value of the assets to REIT shareholders is only MVA - INCTAX, where INCTAX equals the present value of the incremental tax burden faced by the REIT owners. ${ }^{8}$ After taxes, therefore, equation (1) can be rewritten as:

$$
\mathrm{MVE}=\mathrm{MVA}-\mathrm{D}-\mathrm{INCTAX}+\mu
$$

To define INCTAX more precisely, we let it equal $\tau(\mathrm{MVA}-\mathrm{TB})$, where $\tau$ is the capitalized effective tax rate for the marginal investor. A priori, one cannot specify a value for $\tau$ because the marginal investor could be a tax-exempt institution, a high-tax individual, or some other entity. Instead of imposing a value for $\tau$, we infer the value of $\tau$ from the data. Our primary research question then is whether the shareholder tax rate capitalized into share prices is

${ }^{7}$ Real estate values mainly increased during our sample period, so MVA typically exceeds TB.

${ }^{8}$ To focus on the differential taxation of REIT equity and properties, we assume that REIT shareholders face similar tax treatment to the marginal property buyer. We believe that three factors support this assumption. First, both corporate and individual investors in real estate face similar tax rates during our sample period, so it is plausible that these investors capitalize their common tax rate into MVA. Second, many real estate purchases are conducted through organizational forms, such as limited partnerships, that face essentially the same tax consequences as investment through REITs. Third, REITs bought many properties during our sample period, so for any one REIT property, other REITs often are the potential buyer. 
positive, i.e., whether $\tau>0$. However, we also use the magnitudes of our empirical estimates of $\tau$ to infer the tax rate for the marginal investor, although the inference is rough. To illustrate, note that $\tau$ represents the present value of capitalized expected future tax benefits from basis. Therefore if we assume a REIT uses tax basis to generate tax depreciation deductions over a 27.5 year period, as it would for residential rental property, and the after-dividend-tax discount rate for the tax benefits ranges from 4 to 8 percent (low risk is likely to be associated with the future tax benefits), then estimated values for the tax rate for the marginal investor equal between 1.7 (4 percent discount rate) and 2.5 ( 8 percent discount rate) times the estimated value for $\tau$. The midpoint between these two multiples is 2.1, which corresponds to an after-tax discount rate of 6 percent. ${ }^{9}$ As discussed later, we use this midpoint as a rough guide for interpretation of results. Substituting our definition for INCTAX into equation (2) leads to:

$$
\operatorname{MVE}=(1-\tau) \mathrm{MVA}+\tau \mathrm{TB}-\mathrm{D}+\mu .
$$

If the REIT has full tax basis in its assets (i.e., TB is equal to MVA), then the REIT has no incremental tax relative to the outside owner and the expression simplifies back to equation (1). Over time, tax depreciation expenses and changes in asset values can cause the REIT's tax basis

${ }^{9}$ To illustrate, assume the tax basis in a depreciable asset is $\$ 2,750$, the REIT depreciates $\$ 100$ of basis per year, and the tax rate for the marginal investor is 0.396 , so the annual tax savings is $\$ 39.60$. In this case, total tax savings for the 27.5 year period are $\$ 1,089$ (i.e., $27.5 \times \$ 39.60$ ). At a 6 percent discount rate, the present value of the tax savings is $\$ 527$, so $\tau$ is 0.192 (i.e., $\$ 527 / \$ 2,750$ ), and the tax rate for the marginal investor is 2.1 times the value of $\tau$ (i.e., 0.396/0.192). This calculation is subject to errors in either direction. If a REIT's tax basis is composed of non-depreciable assets such as land or securities, or if the REIT owns assets with a 39-year depreciable life, the multiple will rise. However, if the REIT re-classifies certain assets to take advantage of shorter depreciation rules, as they often do, the estimated multiple on $\tau$ would be lower. Also note that our model concentrates on the effects of the REITs' tax basis in their inside assets, while abstracting from investors' outside tax basis in REIT shares. Accounting for the investors' outside tax basis could decrease the estimated value for $\tau$ to some degree (see Malkiel, 1977, for a discussion of this issue in relation to closed-end mutual funds). 
to diverge from the market value of its assets. Equation (3) implies that this divergence drives a wedge between the market value of equity and the market value of assets. If the marginal investor is taxable, then equation (3) leads to the testable prediction that MVE should increase in the firm's inside tax basis in its assets. For REITs, finding that investors assign value to the firm's tax basis is essentially equivalent to finding that investors price dividend taxes.

Rather than focusing on the market value of gross assets, REIT analysts report the market value of net assets $(\mathrm{NAV})$, where NAV $=\mathrm{MVA}-\mathrm{D}$, so that $\mathrm{MVA}=\mathrm{NAV}+\mathrm{D}$. Making this substitution and simplifying results in:

$$
\mathrm{MVE}=(1-\tau) \mathrm{NAV}+\tau \mathrm{TB}-\tau \mathrm{D}+\mu
$$

With this substitution, it is apparent that debt has the opposite tax effect from tax basis. Algebraically, the negative tax effect for debt is a mechanical result of substituting NAV + D for MVA. Intuitively, increasing debt while NAV is constant implies that MVA must increase; because TB remains constant, this increase in MVA is associated with a larger incremental tax burden for the shareholders, and this incremental tax burden decreases equity value at rate $\tau$.

As discussed more fully later, we use two different measures for a REIT's tax basis in its assets. In our first tests, we use the book value of real estate properties (BVA) to measure the tax basis as follows:

$$
\operatorname{MVE}=(1-\tau) \mathrm{NAV}+\tau \mathrm{BVA}-\tau \mathrm{D}+\mu
$$

Like other corporations, however, REITs typically have inside tax basis in all of their assets, not just in their real estate holdings. For example, their tax basis in the securities of other 
corporations equals their original purchase price for the securities. In addition, they have dollarfor-dollar tax basis in cash, which carries over to any other assets they purchase with the cash. In a second set of tests, therefore, we define TB as the book value of total assets. The book value of total assets equals the book value of common equity (BVCE) plus debt, so TB $=\mathrm{BVCE}+\mathrm{D}$.

Defining total tax basis as BVCE $+\mathrm{D}$ is especially appropriate for REITs because they have essentially no retained earnings. Given that REITs distribute their annual income to shareholders, their BVCE consists almost entirely of contributed capital. This is critical, for as Harris and Kemsley (1999) point out, shareholders are taxed on distributions of assets that have been financed with retained earnings. In effect, therefore, shareholders only benefit from the tax basis a firm has in the assets it has financed with contributed capital. That is, contributed capital (or BVCE for REITs) is a summary measure of the amount of assets a firm can distribute to shareholders as a tax-free return of capital.

Substituting BVCE + D for TB in equation (4) and simplifying yields the following alternative valuation equation:

$$
\mathrm{MVE}=(1-\tau) \mathrm{NAV}+\tau \mathrm{BVCE}+\mu
$$

This equation posits that after controlling for NAV, firm value should increase in BVCE, which is our broad measure of the shareholders' portion of a REIT's inside tax basis in its assets. Note that when we substitute BVCE + D for TB, debt falls out of the equation.

Equations (5) and (6) focus on the manner in which shareholder taxes affect the difference between the value of a firm's equity and the value of its assets. We include $\mu$ to capture nontax factors, such as size and liquidity. When moving to empirical work, it is critical 
to control for nontax factors that might be correlated with $\mathrm{TB}$, as discussed in detail later.

\section{Data and Empirical Specification}

\section{A. Data}

Our sample period begins in 1992, which corresponds with a boom in the REIT industry that occurred in the early 1990s. The number of equity REITs grew from 89 in 1992 to 167 in 1999 and their market capitalization grew from $\$ 11$ billion in 1992 to $\$ 118$ billion in $1999 .{ }^{10}$ Furthermore, the average market capitalization of REITs grew as well during the 1990 s, with a consequent gain in liquidity and trading volume.

The REIT boom brought increased analyst coverage. For example, Green Street Advisors, Inc. - our source for NAV estimates - covered 29 REITs in 1992 but 66 REITs by 1999. Green Street provides per share values of NAV. Several factors motivate using the Green Street NAV estimates. Industry observers and participants almost uniformly agree that Green Street produces the most careful and accurate estimates in the REIT industry. It is the only analyst firm to have a consistent set of estimates prior to 1996. Green Street focuses exclusively on real estate firms and each of its analysts follows only a few firms. These analysts specialize by type of property and compute NAV by determining the fair market value of each property owned by a REIT, often visiting larger properties. Finally, Green Street performs no investment banking functions for REITs, so it is immune from the potential conflicts of interest that may impact the research of banks that underwrite securities.

In addition to the NAV estimates from Green Street, we obtain publicly-available

${ }^{10}$ Source: National Association of Real Estate Investment Trusts 
accounting data from SNL Securities, Inc., which covers virtually all REITs, and share price data from the University of Chicago's Center for Research in Security Prices (CRSP). After merging the three data sets, we have 393 REIT-year observations from 85 separate firms. ${ }^{11}$ While Green Street provides NAV estimates for 40 percent of equity REITs in 1999, the firms they cover represent 73 percent of REIT value. Given that REITs do not consistently disclose reliable tax basis information, we use the accounting book value of assets (BVA), which is net of accumulated depreciation, to proxy for the tax basis of the assets. Alternatively, because REITs have very little accumulated retained earnings, we use the book value of common equity for financial accounting purposes as a measure of the REIT's tax basis in its total assets that would be associated with the common equity. Discussions with industry accountants and analysts suggest that book value is a good approximation for the tax basis of most REITs. Furthermore, the financial accounting data provide the only publicly-available proxies for tax basis that investors can use to value REITs.

\section{B. Empirical Specifications}

Given these data, we translate equations (5) and (6) into our empirical equations. Equation (5) suggests using some version of the following equation to estimate tax effects:

$$
\mathrm{MVE}_{\mathrm{it}}=\alpha_{0} \mathrm{NAV}_{\mathrm{it}}+\alpha_{1} \mathrm{BVA}_{\mathrm{it}}+\alpha_{2} \mathrm{D}_{\mathrm{it}}+\mu_{\mathrm{it}}
$$

where the subscripts $i$ and $t$ refer to firms and time periods, respectively. If investors capitalize future shareholder-level taxes into share prices, then we would expect $\alpha_{1}$ to equal $\tau$ and $\alpha_{2}$ to

\footnotetext{
${ }^{11}$ We exclude observations with missing data (or zero) for net properties, with BVCE/NAV < 0.1 , or with real estate properties/total assets $<0.8$. In general, the capital structures of the REITs covered by Green Street are similar to the capital structures of other REITs.
} 
equal $-\tau$, so that $\alpha_{1}=-\alpha_{2}$.

This simple model sweeps a broad array of nontax factors into the error term, $\mu_{\mathrm{it}}$. Although these nontax factors pose potential estimation problems, three factors suggest they are less important for REITs than for other firms. First, analysts use comparable properties to appraise the market value of REIT properties. Therefore, even though NAV may be measured with some error, it is generally much more transparent for REITs than for industrial corporations. Second, tax restrictions on REIT operating and financing decisions, including the requirement to distribute essentially all of their taxable income to shareholders each year, limit the effects of intangible factors like managerial discretion or agency costs. Third, REIT debt often consists of secured, nonrecourse loans, which reduces potential bankruptcy costs. In addition, unlike the high levels of debt incurred by many private real estate owners, the typical REIT has a debt to value ratio of only about 40 percent, suggesting a low probability of bankruptcy.

Despite the fact that these nontax factors are potentially less important for REITs than for industrial firms, they remain a concern. Therefore, we use several measures to control for them and thus reduce the likelihood that our results are driven by a correlation between other factors and our measures of tax basis. For example, REIT shares are much more liquid than real estate properties. If this liquidity has value, then REITs could be valued at a premium relative to NAV. This is especially a concern if liquidity varies across firms and illiquid firms sell at a discount relative to more liquid firms. To control for liquidity and size as determinants of share prices, therefore, we include a dummy variable (SMALL) for small, potentially illiquid firms, equal to one if equity capitalization is less than $\$ 400$ million (which approximately includes the smallest quartile of the sample) and zero otherwise. We also include the average bid-ask spread 
(SPREAD) as a fraction of the midpoint of the bid and ask price for the month of December for each firm-year observation. ${ }^{12}$

An additional complication is that many REITs operate as UPREITs, or umbrella partnership REITs. UPREITs have a separate class of stakeholders who own partnership units that are freely convertible one-for-one into REIT common shares. These partnership units arise when property owners "sell" buildings to a REIT in exchange for the partnership units. Although the partnership units are essentially identical to shares, they allow property owners to defer capital gains taxes when "selling" buildings to a REIT. Given this tax advantage, UPREITs have become quite popular; approximately 82 percent of our observations come from UPREITs. ${ }^{13}$ To properly account for UPREITS, therefore, we include the partnership units as common shares in our regressions, and as an additional control, we also include a firm-level dummy variable equal to one for UPREITs. ${ }^{14}$

Finally, because we focus on the valuation of common equity, we control for the book value of preferred stock (BVPE). The coefficient on preferred stock has the same predictions as the coefficient on the debt variable. However, preferred stock is concentrated among a few

\footnotetext{
${ }^{12}$ We construct the spread variable from the NYSE's TAQ data. We use December data because it corresponds most closely with year-end stock prices and NAV. We equally weight all quotes from the month but we exclude quotes from regional exchanges. Due to data constraints, we use data from January 1993 for December 1992.

${ }^{13}$ See Sinai and Gyourko, 2000, for details regarding the UPREIT structure.

${ }^{14}$ Sagalyn (1996) argues that UPREITs face certain conflicts of interest and restrictions on sales and refinancings that could reduce firm value relative to NAV. If a REIT has acquired assets through an UPREIT transaction, refinancing assets or selling through a "like-kind exchange" may trigger a capital gain for the original property contributor. In many UPREITs, these contributors include the current managers. The potentially large tax liabilities triggered by these transactions may discourage such managers from undertaking certain transactions that would be in the best interest of outside shareholders.
} 
REITs, so this variable may also capture any unobserved differences between REITs that issue preferred stock and those that do not. ${ }^{15}$

In addition to observable factors, unobservable factors may affect MVE. For example, investor sentiment may affect share prices. Indeed, Clayton and MacKinnon (2000) find a common time-series component in REIT share prices relative to property values, which is consistent with time-series variation in investor sentiment affecting REIT share prices. To control for time effects, we include year-specific intercepts and we allow the coefficient on NAV to vary by year. By estimating separate coefficients on NAV for each year, we allow investor sentiment to affect the ratio of average REIT share prices relative to NAV.

The error term in equation (7) may also include an unobservable firm-specific (but timeinvariant) component. For example, managerial ability could vary across firms. If this firmspecific component is uncorrelated with the other regressors, then estimating an ordinary-leastsquares (OLS) model would generate consistent but inefficient estimates of the parameters, and estimating a random-effects model (i.e., generalized least squares) would generate consistent, efficient estimates. If the firm-specific component is correlated with the other regressors, however, then both the OLS and random-effects estimates may be biased. In this case, it is necessary to use firm fixed effects to avoid bias. Nevertheless, estimating a fixed-effects model consumes a large number of degrees of freedom. In our sample, we have data for 85 REITs that are in the panel for an average of 4.6 years. With a relatively short panel, using firm fixed effects

\footnotetext{
${ }^{15}$ For example, market analysts report that only "top-flight" REITs issue preferred stock because investors are averse to buying preferred from weaker REITs (see Schwimmer,1995). Overall, preferred stock is a small component of REITs' capital structure. Only about one-third of the REIT-years in our sample use preferred stock, and for these REITs, the average amount of preferred is approximately 7 percent of NAV.
} 
may exacerbate measurement error and lead to noisy parameter estimates.

Given the relative strengths and weaknesses of the different methods of controlling for the firm-specific component of the error term, we present OLS estimates (as a naive benchmark) and both random and fixed-effects estimates for the following equation:

$$
\mathrm{MVE}_{\mathrm{it}}=\sum_{\mathrm{t}} \gamma_{\mathrm{t}} \mathrm{NAV}_{\mathrm{it}}+\alpha_{1} \mathrm{BVA}_{\mathrm{it}}+\alpha_{2} \mathrm{D}_{\mathrm{it}}+\alpha_{3} \mathrm{BVPE}_{\mathrm{it}}+\sum_{\mathrm{j}} \delta_{\mathrm{j}} \mathrm{X}_{\mathrm{jit}}+\sum_{\mathrm{t}} \phi_{\mathrm{t}}+\sum_{\mathrm{i}} \theta_{\mathrm{i}}+\varepsilon_{\mathrm{it}}
$$

where the $\gamma_{\mathrm{t}}$ are the year-specific coefficients for NAV, $X_{\mathrm{jit}}$ are the observable firm-specific characteristics $\left(\delta_{\mathrm{j}}\right.$ are the associated coefficients $), \phi_{\mathrm{t}}$ are the year-specific constants, $\theta_{\mathrm{i}}$ are the firm-specific components of the error term (specified with either random or fixed effects), and $\epsilon$ captures any remaining error. In measuring MVE, we multiply the common share price times the number of common shares outstanding plus the number of convertible partnership units outstanding. Similarly, in measuring NAV, we multiply the NAV per share estimates from Green Street by the number of common shares outstanding plus the number of convertible partnership units outstanding. We use both common shares and convertible partnership units to measure MVE and NAV because REITs use both shares and units to finance BVA, which is our measure of tax basis.

In equation (8), we express the variables in levels form. However, REITs vary considerably in size, so this specification could suffer from heteroscedastic errors. To control for potential heteroscedasticity, we also estimate the following equation:

$$
\frac{\mathrm{MVE}_{\mathrm{it}}}{\mathrm{NAV}_{\mathrm{it}}}=\alpha_{1} \frac{\mathrm{BVA}_{\mathrm{it}}}{\mathrm{NAV}_{\mathrm{it}}}+\alpha_{2} \frac{\mathrm{D}_{\mathrm{it}}}{\mathrm{NAV}_{\mathrm{it}}}+\alpha_{3} \frac{\mathrm{BVPE}_{\mathrm{it}}}{\mathrm{NAV}_{\mathrm{it}}}+\sum_{\mathrm{j}} \delta_{\mathrm{j}} \mathrm{X}_{\mathrm{jit}}+\sum_{\mathrm{t}} \phi_{\mathrm{t}}+\sum_{\mathrm{i}} \theta_{\mathrm{i}}+\varepsilon_{\mathrm{it}}
$$

While scaling by NAV mitigates potential heteroscedasticity, it also could magnify the effects of 
any measurement error in NAV, inducing a positive bias in the estimated BVA and D coefficients. If measurement error in NAV is a problem, scaling by NAV should make it easier to reject the hypothesis that $\alpha_{1}=-\alpha_{2}$.

In a second set of tests, we follow equation (6) by using BVCE in lieu of BVA to measure tax basis in equations (8) and (9); this yields the following equations:

$$
\begin{aligned}
& \mathrm{MVE}_{\mathrm{it}}=\sum_{\mathrm{t}} \gamma_{\mathrm{t}} \mathrm{NAV}_{\mathrm{it}}+\alpha_{1} \mathrm{BVCE}_{\mathrm{it}}+\alpha_{2} \mathrm{D}_{\mathrm{it}}+\alpha_{3} \mathrm{BVPE}_{\mathrm{it}}+\sum_{\mathrm{j}} \delta_{\mathrm{j}} \mathrm{X}_{\mathrm{jit}}+\sum_{\mathrm{t}} \phi_{\mathrm{t}}+\sum_{\mathrm{i}} \theta_{\mathrm{i}}+\varepsilon_{\mathrm{it}}, \\
& \frac{\mathrm{MVE}_{\mathrm{it}}}{\mathrm{NAV}_{\mathrm{it}}}=\alpha_{1} \frac{\mathrm{BVCE}_{\mathrm{it}}}{\mathrm{NAV}_{\mathrm{it}}}+\alpha_{2} \frac{\mathrm{D}_{\mathrm{it}}}{\mathrm{NAV}_{\mathrm{it}}}+\alpha_{3} \frac{\mathrm{BVPE}_{\mathrm{it}}}{\mathrm{NAV}_{\mathrm{it}}}+\sum_{\mathrm{j}} \delta_{\mathrm{j}} \mathrm{X}_{\mathrm{jit}}+\sum_{\mathrm{t}} \phi_{\mathrm{t}}+\sum_{\mathrm{i}} \theta_{\mathrm{i}}+\varepsilon_{\mathrm{it}}
\end{aligned}
$$

Our measure of MVE includes the value of convertible partnership units, so we include the book value of these interests (recorded as minority interests in the financial statements) in our measure of BVCE. ${ }^{16}$ If investors capitalize tax basis into share prices, then we expect $\alpha_{1}$ to be positive. When using BVCE as our measure of tax basis, we expect the debt coefficient $\left(\alpha_{2}\right)$ to be zero (see equation (6) and the related discussion). However, we include debt and preferred stock in the equation to control for possible effects of capital structure on firm value.

The actual magnitudes of our estimates for $\tau$ should depend on the identity of the marginal investor, as well as on the applicable tax rate and the timing of the tax benefits for shareholders. A priori, it is not possible to identify the marginal investor in REIT shares. As high-dividend-yield stocks, it could be argued that REITs should attract investors that pay little

\footnotetext{
${ }^{16}$ Our results are similar if we do not include partnership units in the dependent variable and also exclude minority interests from BVCE.
} 
or no tax on dividends, such as corporations or tax-exempt institutions. ${ }^{17}$ However, the corporate tax deduction for intercorporate dividends does not apply to dividends from REITs, so corporations do not have a tax incentive to invest in REITs. In addition, approximately half of all REITs make voluntary nontaxable return-of-capital distributions to shareholders, which should be attractive to high-tax investors. Given these ambiguities regarding the natural tax clientele for REITs, we do not impose any assumptions regarding the marginal clientele. Instead, we simply infer the applicable tax rate from the data.

\section{Potential Measurement Error}

Despite Green Street's best efforts to estimate NAV, real estate markets are often relatively thin. ${ }^{18}$ Therefore we are concerned about potential measurement error in NAV. For example, suppose reported NAV equals true NAV $\left(\mathrm{NAV}^{\mathrm{T}}\right)$ plus an error term, so NAV $=\mathrm{NAV}^{\mathrm{T}}$ $+\eta$. The error term is probably best described as an "optimal prediction error." As discussed by Hyslop and Imbens (2000), an optimal prediction error occurs when the error is correlated with the true value of a variable but is independent of the reported value. An example of this type of error would be an agent gathering several noisy signals of the true variable and processing these signals into a "best" estimate of the truth, which describes the process analysts use to generate NAV estimates. Under this type of error, the biases in the coefficient estimates depend on the correlation between the error and the variables of interest.

${ }^{17}$ Empirically, Chan, Leung, and Wang (1998) report that institutional ownership of REITs was similar to other corporations over their sample from 1984 to 1995 . However, the term "institutional investor" mixes taxable and tax-exempt investors so it is unclear how well it captures tax clienteles.

${ }^{18}$ Most REITs in our sample own large investment grade properties that tend to have a number of well-capitalized potential buyers. The sample also occurs at a time when real estate markets are improving. Anecdotal evidence suggests that liquidity has not been a big issue over this time period. 
Whether any estimation error in NAV is correlated with BVA or D is unclear because Green Street analysts have access to data on BVA and D when estimating NAV. Nevertheless, given the potential for bias, we take three steps to provide some assurance that measurement error does not materially influence our results. First, we focus on the hypothesis that $\alpha_{1}=-\alpha_{2}$. The bias in the estimated BVA coefficient depends on the covariance between BVA and $\eta$, whereas the bias in the estimated D coefficient depends on the covariance between D and $\eta$. Unless measurement error biases $\alpha_{1}$ and $\alpha_{2}$ by a similar magnitude but opposite sign, substantial measurement error would lead us to reject our hypothesis that $\alpha_{1}=-\alpha_{2}$. Second, we conduct sensitivity tests in which we add control variables for factors that may be correlated with $\eta$. If the estimated coefficients for BVA or D are driven by correlation between BVA or D and $\eta$, then adding the control variables should reduce the magnitude of the estimated BVA and D coefficients. Third, we directly address potential measurement error biases by regressing future profits on NAV and BVCE. If noise in NAV biases the estimated BVCE coefficient when we regress MVE on NAV and BVCE, then we would generally expect to find a similar bias when we regress future profits on NAV and BVCE. We discuss the rationale for this test in more detail in the empirical section below.

\section{Empirical Results}

\section{A. Descriptive Statistics}

As reported in Table I, the mean MVE/NAV ratio is 1.08 . In contrast to the discount that would result from tax factors alone, REITs trade at an average premium over the market value of assets for our sample period. This premium may reflect nontax benefits of the REIT form of 
organization, such as the value of public trading or managerial talent, suggesting it is important to control for nontax factors. On average, sample REITs hold 95 percent of their total assets in real estate properties. The mean dividend yield is a rather high 6.9 percent, reflecting the dividend distribution requirement for REITs.

\section{B. Primary Results}

In Panel A of Table II, we report results from estimating equation (8). The estimated BVA coefficient is positive and statistically significant at the 95 percent confidence level whether we estimate the equation with OLS (0.17), random effects $(0.19)$, or fixed effects $(0.25)$, which is consistent with the hypothesis that investors capitalize dividend tax savings from tax basis into share prices. ${ }^{19}$ Also consistent with expected tax effects, the estimated D coefficient is negative and statistically significant at the 95 percent confidence level whether we use OLS $(-0.15)$, random effects $(-0.18)$, or fixed effects $(-0.27)$. Furthermore, we cannot reject our prediction that $\alpha_{1}=-\alpha_{2}$; the absolute value of the estimated D coefficient is not statistically different from the estimated BVA coefficient for any of the specifications. The similarity of our BVA and D estimates of the implied tax rate provides some preliminary evidence that measurement error does not materially bias our estimates of the capitalized tax rate. ${ }^{20}$

\footnotetext{
${ }^{19}$ Hausman specification tests indicate that the random effects and fixed effects specifications are statistically different from each other (with a p-value of 0.001) in Panels A and B of both Tables II and III.

${ }^{20}$ Equation (5) implies $\tau$ equals one minus the estimated NAV coefficient. To exploit this prediction, in a supplementary test, we restrict the estimated NAV coefficient to be constant across years. Imposing this restriction drops our control for investor sentiment and related unobservable factors that vary across years, which reduces the reliability of our estimates; furthermore, F-tests reject imposing this restriction at the 99 percent confidence level. Nevertheless, the estimated NAV coefficients are largely consistent with predictions; they are 0.88 (OLS), 0.86 (random effects), and 0.67 (fixed effects), so the implied estimates of $\tau$ are 0.12 (OLS), 0.14 (random effects), and 0.33 (fixed effects), with the random effects and fixed effects estimates statistically different from zero at the 95 percent confidence level. In
} 
In Panel B of Table II, we report results from estimating equation (9) in which we scale the regression variables by NAV. The estimated BVA (D) coefficients remain positive (negative) and statistically significant at the 95 percent confidence level, but scaling the variables by NAV reduces the magnitude of the coefficients. Specifically, the estimated BVA (D) coefficients are $0.091(-0.089), 0.093(-0.095)$, and $0.18(-0.19)$ when using OLS, random effects, and fixed effects, respectively. As in Panel A, the absolute values of the estimated D coefficients in Panel B are not statistically different from the estimated BVA coefficients as predicted. Hence the evidence in both panels of Table II suggests that investors capitalize substantial shareholder taxes in REIT share prices, but the magnitudes of the estimates depend on the specifications used.

The estimated BVPE coefficient is positive in the OLS specifications which is inconsistent with a tax interpretation, suggesting that highly-regarded REITs may issue preferred equity. Consistent with this interpretation, when we use fixed effects to control for unobserved differences in REIT quality, the estimated BVPE coefficient is negative, which is consistent with predicted tax effects. Given the conflicting effects from the preferred equity variable, we concentrate on the estimated tax rates associated with tax basis and debt. ${ }^{21}$

In regard to the other variables, small REITs trade at a discount relative to larger REITs. Consistent with illiquidity being associated with a discount relative to NAV, the estimated

addition, imposing the restriction on the NAV coefficient does not alter the signs of the estimated BVA and $\mathrm{D}$ coefficients.

${ }^{21}$ As an alternative to estimating separate coefficients for BVA, D, and BVPE, we combine these variables into a single measure of the incremental tax burden for a REIT by subtracting the tax basis proxy (BVA) from the gross value of properties (measured as the sum of NAV, D, and BVPE). For the six specifications presented in Table II, this restricted regression yields estimated values for $\tau$ ranging from 0.094 to 0.25 , all of which are statistically different from zero at the 95 percent confidence level. 
SPREAD coefficient is negative and statistically different from zero in the OLS and random effects specifications; using the coefficient estimate from the random effects specification in Panel B, a one standard deviation decrease in SPREAD (an increase in liquidity) increases MVE relative to NAV by 2.57 percentage points. However, this coefficient is imprecisely estimated in the fixed effects specifications, suggesting that between-firm variation in liquidity is more important than within-firm variation in liquidity.

In Table III, we report results from estimating equations (10) and (11), in which we use BVCE in place of BVA to measure tax basis. As previously noted, BVCE captures tax basis in all assets, not just tax basis in real estate properties. When using the variables as levels (Panel A), the estimated BVCE coefficients are positive and statistically different from zero when using ordinary least squares $(0.15)$, random effects $(0.097)$, and fixed effects $(0.19) .{ }^{22}$ When scaling the variables by NAV (Panel B), the estimated coefficients remain positive and statistically significant, and are equal to 0.090 for OLS, 0.096 for random effects, and 0.20 for fixed effects. In contrast to predictions, the estimated debt coefficient is positive and statistically significant at the 95 percent confidence level in columns (1) and (2) of Panel A of Table III (i.e., the OLS and random effects specifications). Consistent with expectations, however, it is statistically insignificant in all other specifications.

The estimated tax rates from Tables II and III range from 9 to 27 percent, with OLS and

\footnotetext{
${ }^{22}$ When restricting the estimated NAV coefficient to be constant across years, the estimated NAV coefficients are 0.78 (OLS), 0.83 (random effects), and 0.70 (fixed effects). In accordance with equation (6), the implied estimates of $\tau$ equal one minus the estimated NAV coefficients, or 0.22 (OLS), 0.17 (random effects), and 0.30 (fixed effects), all of which are statistically different from zero at the 95 percent confidence level. In addition, the estimated BVCE coefficient remains positive in all three specifications. Once again, F-tests reject this restriction at the 99 percent confidence level.
} 
random effects specifications yielding lower estimates than the fixed effects specifications. Most of the estimates (i.e., 16 out of 18) range from 9 to 20 percent. These estimates reflect the discounted value of future tax benefits from existing tax basis in properties. If we assume the implied undiscounted tax rate equals approximately 2.1 times the discounted rate as suggested by the example in Section II, then most of the estimated undiscounted tax rates range from 18 to 42 percent, with a midpoint of approximately 30 percent. By way of comparison, the top Federal tax rate on dividends for individual investors for most of the sample period is 39.6 percent.

The high fixed-effects estimates suggest it is unlikely that omitted, time-invariant firm characteristics create positive bias in the OLS or random effects estimates. Instead, if these omitted variables bias the OLS or random effects estimates, the bias appears to reduce estimated tax rates. Given the relatively short time dimension of our data, however, the fixed-effects estimates should be viewed with caution.

To the extent investors do, indeed, capitalize shareholder-level taxes into REIT share prices, REIT investment is on essentially equal footing with direct real estate investment, at least from a tax perspective. When investors directly purchase real estate properties through proprietorships or partnerships, they typically benefit from early depreciation deductions that they recapture as taxable gains (along with appreciation) when they sell the properties. In the absence of tax capitalization, however, REIT investors could consume depreciation tax shields without ever having to recapture the deductions as taxable gains by merely selling their shares on the secondary market before the REITs sold the underlying properties. However, the evidence in Tables II and III suggests that new REIT investors implicitly charge sellers for the tax depreciation deductions they have consumed, as well as for any unpaid taxes on property 
appreciation, via lower purchase prices for the stock.

\section{Controlling for the Potential Effects of Measurement Error}

As previously discussed, any correlation between measurement error in NAV and BVA, BVCE, or D could bias our estimated tax rates. If this bias accounts for the positive BVA and BVCE coefficients in Tables II and III, or for the negative D coefficients in Table II, then we would expect the magnitude of the bias to decrease as we add other explanatory variables to the regression. For example, controlling for current and future cash flows, or Funds From Operations (FFO), may mitigate measurement error bias. ${ }^{23}$ If FFO is correlated with the measurement error in NAV, and if the measurement error in NAV contributes to the positive estimated BVA coefficient and the negative estimated D coefficient, then controlling for FFO should reduce the magnitudes of the BVA and D coefficients.

To examine this possibility, we estimate equation (8) after adding current FFO and next period's FFO. In the random effects specification, the estimated coefficient for current FFO (which is observable to Green Street when estimating NAV) is $-0.67(t=-1.8)$, and the estimated coefficient for future FFO (which is not observable to Green Street when estimating NAV) is $2.31(\mathrm{t}=5.2)$. Hence FFO, especially future FFO, provides incremental value-relevant information that is not captured by Green Street's estimate of NAV. ${ }^{24}$ Nevertheless, including

${ }^{23}$ FFO is the most commonly used measure of cash flow in the real estate industry. Since FFO is unavailable for some REITs in our database and future FFO requires shortening the sample period, including these variables decreases sample size by 35 percent. The inferences we draw from adding FFO are not sensitive to using only a subsample of the observations in our main specification.

${ }^{24}$ In specifications that include current FFO but not future FFO, the estimated coefficient on current FFO is not statistically different from zero, suggesting that the effect of current FFO depends on including future FFO in the regression. 
these two control variables does not reduce the magnitudes of the BVA and D coefficients. Instead, the magnitudes of the estimated BVA and D coefficients increase to $0.23(t=7.2)$ and $-0.22(\mathrm{t}=-5.6)$, respectively. Qualitatively similar results occur when adding FFO to our other specifications. Thus, these results mitigate at least some of the concern that measurement error could drive our primary results.

In a final test, we more directly examine the potential effects of measurement error by testing whether the book value of common equity (BVCE) has predictive power for future profitability after controlling for NAV. If the predictive power of book value is related to taxes alone as we have assumed, then book value should predict the after-tax value of the firm (as measured by MVE), but not the pretax value of the firm. To conduct this robustness test, we use the book value of common equity (BVCE) instead of the book value of assets (BVA), so that all of the variables in the regression are net of debt (i.e., NAV is net of debt and earnings are net of interest payments).

The pretax market value of equity for a REIT (PMVE) can be represented as the present discounted value of its future cash flows plus other factors or:

$$
\operatorname{PMVE}_{i t}=\sum_{s=t}^{\infty} \rho^{-s} \pi_{\text {is }}+\mu_{\text {is }} \text {, }
$$

where $\rho$ is the discount factor (i.e., one plus the appropriate discount rate), $\pi_{\text {is }}$ are the pretax cash flows that firm i earns in period $\mathrm{s}$, and $\mu$ represents all other factors that may affect PMVE. If we had the infinite stream of future pretax REIT cash flows, as well as the appropriate discount rate, we could estimate the pretax value of the firm's equity. We could then regress PMVE on NAV 
and BVCE, and the estimated BVCE coefficient would reflect nontax valuation effects from book value that are not captured by NAV. While we do not have the full path of future cash flows, the same logic applies to a regression of future earnings on NAV and BVCE over a shorter horizon. After controlling for NAV, any relation between BVCE and future earnings should reflect the inadequacies of NAV in predicting future earnings that are captured by book value. As reported in Table IV, the estimated NAV coefficient is positive and significant at the 95 percent confidence level when we regress future cash flows on NAV and BVCE, whether we use the next year's FFO, or the sum of FFO for the next three years, as a proxy for future cash flows. In contrast, the estimated BVCE coefficient is not statistically different from zero (with tstatistics less than one). These findings suggest that even if measurement error in NAV is material, it does not appear to be correlated with BVCE. Like the other results in this subsection, therefore, the results in Table IV are consistent with a tax interpretation for the positive book value coefficient in the primary tests.

\section{Conclusion}

In this study, we exploit four characteristics of REITs to estimate the influence of shareholder-level taxes on share prices. First, a REIT's tax basis in its assets provides depreciation tax shields and reduces taxable gains on the sale of properties. Second, REITs do not pay corporate taxes, so any benefit they derive from tax basis reduces shareholder-level taxes only. Third, analysts regularly appraise the market value of REIT properties, and the tax basis REITs have in their properties invariably differs from the market value of the assets. Fourth, REITs are required to pay out most of their taxable income as dividends, limiting the extent to 
which these firms can use dividends for signaling purposes and eliminating the tax benefit associated with share repurchases as a substitute for dividends. Given this institutional setting, we design tests to examine the hypothesis that investors capitalize the shareholder-level tax benefits from tax basis into share prices, after controlling for the market value of the assets.

Our evidence indicates that each dollar of tax basis increases REIT share prices by 9 to 27 cents, conditional on the fair market value of properties, with most estimates ranging from 9 to 20 cents. Although the potential effects of omitted nontax factors remain a concern, these estimates are robust to a variety of specifications. Furthermore, after controlling for NAV, book value has incremental predictive power for the after-tax value of the firm (as measured by share prices) but not for the pretax value of the firm (as measured by future pretax cash flows), which provides some comfort that measurement error in NAV is not driving our findings.

By focusing on REITs, we have been able to control for many of the investment and dividend policy issues that complicate the analysis for other corporations. In particular, we find investors capitalize a substantial amount of dividend taxes into prices when dividend policy is largely non-discretionary, there are no corporate taxes, and share repurchases do not offer a tax advantage relative to dividends. This result casts doubt on the tax irrelevance hypothesis that asset prices are determined by investors who are indifferent to taxes. While our study focuses on a single industry, we believe our findings provide a benchmark for future examinations of the share price effects of dividend taxes in more complex settings. 


\section{References}

Auerbach, Alan J., 1979, Share valuation and corporate equity policy, Journal of Public Economics 11: 291-305.

Bali, Rakesh, and Gailen L. Hite, 1998, Ex-dividend day stock price behavior: Discreteness or tax-induced clienteles?, Journal of Financial Economics 47: 127-159.

Barclay, Michael J., 1987, Dividends, taxes, and common stock prices: The ex-dividend day behavior of common stock prices before the income tax, Journal of Financial Economics 19: 31-43.

Black, Fischer and Myron Scholes, 1974, The effects of dividend yield and dividend policy on common stock prices and returns, Journal of Financial Economics 1: 1-22.

Blume, Marshall E., 1980, Stock returns and dividend yields: Some more evidence, Review of Economics and Statistics 62: 567-577.

Bradford, David F., 1981, The incidence and allocation effects of a tax on corporate distributions, Journal of Public Economics 15: 1-22.

Brennan, Michael J., 1970, Taxes, market valuation and corporate financial policy, National Tax Journal 23: 417-427.

Brueggeman, William B. and Jeffrey D. Fisher, 1997, Real Estate Finance and Investments, Irwin (Boston), 10th Edition, Chapter 21: 661-79.

Chan, Su Han, Wai Kin Leung, and Ko Wang, 1998, Institutional investment in REITs: Evidence and implications, Journal of Real Estate Research 16: 357-374.

Chen, Nai-Fu, Bruce Grundy, and Robert F. Stambaugh, 1990, Changing risk, changing risk premiums and the dividend yield effect, Journal of Business 63: 178-206.

Clayton, Jim and Greg MacKinnon, 2000, Explaining the discount to NAV in REIT Pricing: Noise or information? Working Paper, University of Cincinnati.

Cutler, David M., 1988, Tax reform and the stock market: An asset price approach, American Economic Review 78: 1107-1117.

Elton, Edwin J. and Martin J. Gruber, 1970, Marginal stockholder tax rates and the clientele effect, Review of Economics and Statistics 52: 68-74.

Fama, Eugene F. and Kenneth R. French, 1993, Common risk factors in the returns on stocks and 
bonds, Journal of Financial Economics 33, 3-56.

Fama, Eugene F. and Kenneth R. French, 1998, Taxes, financing decisions, and firm value, Journal of Finance 53: 819-843.

Frank, Murray, and Ravi Jagannathan, 1998, Why do stock prices drop by less than the value of the dividend? Evidence from a country without taxes, Journal of Financial Economics 47: $161-188$.

Givoly, Dan and Carla Hayn, 1991, The aggregate and distributional effects of the tax reform act of 1986 on firm valuation, Journal of Business 64: 363-392.

Gordon, Roger and David Bradford, 1980, Taxation and the stock market valuation of capital gains and dividends: Theory and empirical results, Journal of Public Economics 14: 109136.

Green, Richard C., and Burton Hollifield. 2001, The personal-tax advantages of equity, Working Paper, Carnegie Mellon University.

Green, Richard C., and Kristian Rydqvist, 1999, Ex-day behavior with dividend preference and limitations to short-term arbitrage: The case of swedish lottery bonds, Journal of Financial Economics 53: 145-187.

Harris, Trevor S., and Deen Kemsley, 1999, Dividend taxation in firm valuation: New evidence, Journal of Accounting Research 37: 275-292.

Hyslop, Dean R., and Guido W. Imbens., 2000, Bias from classical and other forms of measurement error, NBER Technical Working Paper 257, Cambridge, MA.

Kalay, A., 1982, The ex-dividend day behavior of stock prices: A re-examination of the clientele effect, Journal of Finance 37: 1059-1070.

Karpoff, J. M., and R. A. Walkling, 1988, Short-term trading around ex-dividend days additional evidence, Journal of Financial Economics 21: 291-298.

King, Mervyn, 1977, Public Policy and the Corporation, London: Chapman and Hall.

Lamdin, Douglas J., and Craig Hiemstra, 1993, Ex-dividend day share price behavior: Effects of the tax reform act of 1986," Review of Economics and Statistics 75: 778-783.

Litzenberger, R. and K. Ramaswamy, 1979, The effect of personal taxes and dividends on capital asset prices: Theory and empirical evidence, Journal of Financial Economics 7: 163-195. 
Litzenberger, R. and K. Ramaswamy, 1982, The effects of dividends on common stock prices: Tax effects or information effects?, Journal of Finance 37: 429-443.

Malkiel, Burton G., 1977, The valuation of closed-end investment-company shares, Journal of Finance 32: 847-859.

Miller, Merton H., and Myron Scholes, 1978, Dividends and taxes, Journal of Financial Economics 6: 333-364.

Miller, Merton H., and Myron Scholes, 1982, Dividends and taxes: Some empirical evidence, Journal of Political Economy 90: 1118-1141.

Naranjo, Andy, M. Nimalendran, and Mike Ryngaert, 1998, Stock returns, dividend yields, and taxes, Journal of Finance 53: 2029-57.

Naranjo, Andy, M. Nimalendran, and Mike Ryngaert, 2000, Time variation of ex-dividend day stock returns and corporate dividend capture: A reexamination, Journal of Finance 55: 2357-2372.

Poterba, James M., and Lawrence H. Summers, 1984, New evidence that taxes affect the valuation of dividends, Journal of Finance 39: 1397-1415.

Rosenberg, B., and V. Marathe, 1979, Tests of capital pricing hypotheses, Research in Finance 1: $115-223$.

Sagalyn, Lynne, 1996, Conflicts of interest in the structure of REITs, Real Estate Finance, 13: 34-51.

Schwimmer, Anne, 1995, Underwriters attract REITs to swooning preferred market, Investment Dealers' Digest (May 29): 13.

Sinai, Todd and Joseph Gyourko, 2000, The asset price incidence of capital gains taxes: Evidence from the taxpayer relief act of 1997 and publicly-traded real estate firms, Wharton School mimeo, November.

White, H., 1980, A heteroskedasticity-consistent covariance matrix estimator and a direct test for heteroskedasticity, Econometrica , 48: 817-838. 
Table I

Summary Statistics for REIT Sample

\begin{tabular}{|l|c|c|c|}
\cline { 2 - 4 } \multicolumn{1}{c|}{} & Mean & Median & Standard Deviation \\
\hline MVE & 1050.0 & 732.0 & 1100.0 \\
\hline BVA & 1510.0 & 794.0 & 1990.0 \\
\hline D & 766.0 & 394.0 & 1100.0 \\
\hline BVPE & 92.4 & 0 & 185.0 \\
\hline BVCE & 643.0 & 348.0 & 858.0 \\
\hline MVE/NAV & 1.08 & 1.07 & 0.21 \\
\hline BVA/NAV & 1.41 & 1.41 & 0.44 \\
\hline D/NAV & 0.72 & 0.69 & 0.35 \\
\hline BVPE/NAV & 0.07 & 0 & 0.10 \\
\hline BVCE/NAV & 0.56 & 0.55 & 0.23 \\
\hline SMALL & 0.23 & 0 & 0.42 \\
\hline SPREAD & 0.010 & 0.0096 & 0.0041 \\
\hline UPREIT & 0.82 & 1 & 0.39 \\
\hline $\begin{array}{l}\text { Proportion of Total Assets } \\
\text { in Net Properties }\end{array}$ & 0.95 & 0.95 & 0.03 \\
\hline Dividend Yield (\%) & 6.9 & 6.8 & 2.6 \\
\hline
\end{tabular}

All variables have 393 observations except for dividend yield (392 observations). Dollar figures are in millions of dollars. MVE is the market value of common equity (including the value of OP units in UPREITs), BVA is the book value of real estate properties, which proxies for tax basis in inside assets, D is the book value of debt, BVPE is the book value of preferred equity, BVCE is the book value of common equity, NAV is the net (of liabilities) market value of assets, SMALL is a dummy variable equal to one if total market capitalization is less than $\$ 400$ million, SPREAD is the average bid-ask spread as a fraction of the midpoint of the bid and ask prices for the month of December, and UPREIT is a dummy variable equal to one if the REIT is an umbrella partnership. 
Table II

Regressions Measuring Tax Basis with Property Value

\begin{tabular}{|c|c|c|c|}
\hline \multicolumn{4}{|c|}{ Panel A: Dependent Variable: MVE } \\
\hline Variable & $\begin{array}{c}\text { (1) } \\
\text { Ordinary Least } \\
\text { Squares }\end{array}$ & $\begin{array}{c}\text { (2) } \\
\text { Random Effects }\end{array}$ & $\begin{array}{c}(3) \\
\text { Firm Fixed } \\
\text { Effects }\end{array}$ \\
\hline BVA & $\begin{array}{l}0.17^{* *} \\
(0.071)\end{array}$ & $\begin{array}{l}0.19^{* * *} \\
(0.026)\end{array}$ & $\begin{array}{l}0.25^{* * *} \\
(0.048)\end{array}$ \\
\hline $\mathrm{D}$ & $\begin{array}{l}-0.15^{* * *} \\
(0.055)\end{array}$ & $\begin{array}{l}-0.18^{* * *} \\
(0.030)\end{array}$ & $\begin{array}{l}-0.27^{* * *} \\
(0.069)\end{array}$ \\
\hline BVPE & $\begin{array}{l}0.16^{* *} \\
(0.079)\end{array}$ & $\begin{array}{c}0.093 \\
(0.065)\end{array}$ & $\begin{array}{l}-0.15 \\
(0.091)\end{array}$ \\
\hline SMALL & $\begin{array}{l}-32.0^{* * *} \\
(22.8)\end{array}$ & $\begin{array}{l}-43.1^{*} \\
(20.9)\end{array}$ & $\begin{array}{l}-37.2 \\
(22.9)\end{array}$ \\
\hline SPREAD & $\begin{array}{c}-10300.0^{* * *} \\
(2430.0)\end{array}$ & $\begin{array}{l}-6130.0^{* * *} \\
(1970.0)\end{array}$ & $\begin{array}{l}-2220.0 \\
(2070.0)\end{array}$ \\
\hline UPREIT & $\begin{array}{l}-32.0 \\
(22.8)\end{array}$ & $\begin{array}{c}-1.98 \\
(26.8)\end{array}$ & - \\
\hline R-squared & 0.99 & 0.99 & 0.98 \\
\hline $\begin{array}{l}\text { F-test p-value: } \alpha_{1}=- \\
\alpha_{2}\end{array}$ & 0.58 & 0.54 & 0.64 \\
\hline
\end{tabular}

Table notes are after Panel B. 
Table II

Regressions Measuring Tax Basis with Property Value

\begin{tabular}{|c|c|c|c|}
\hline \multicolumn{4}{|c|}{ Panel B: Dependent Variable: MVE/NAV } \\
\hline Variable & $\begin{array}{c}(1) \\
\text { Ordinary Least } \\
\text { Squares }\end{array}$ & $\begin{array}{c}\text { (2) } \\
\text { Random Effects }\end{array}$ & $\begin{array}{c}\text { (3) } \\
\text { Firm Fixed } \\
\text { Effects }\end{array}$ \\
\hline $\mathrm{BVA} / \mathrm{NAV}$ & $\begin{array}{l}0.091^{* *} \\
(0.039)\end{array}$ & $\begin{array}{l}0.093^{* *} \\
(0.040)\end{array}$ & $\begin{array}{l}0.18^{* * *} \\
(0.067)\end{array}$ \\
\hline $\mathrm{D} / \mathrm{NAV}$ & $\begin{array}{l}-0.089^{* *} \\
(0.040)\end{array}$ & $\begin{array}{l}-0.095^{* *} \\
(0.049)\end{array}$ & $\begin{array}{l}-0.19^{* *} \\
(0.079)\end{array}$ \\
\hline BVPE/NAV & $\begin{array}{c}0.013 \\
(0.091)\end{array}$ & $\begin{array}{l}-0.039 \\
(0.086)\end{array}$ & $\begin{array}{l}-0.22^{*} \\
(0.11)\end{array}$ \\
\hline SMALL & $\begin{array}{l}-0.11^{* * *} \\
(0.018)\end{array}$ & $\begin{array}{l}-0.12^{* * *} \\
(0.021)\end{array}$ & $\begin{array}{l}-0.096^{* * *} \\
(0.025)\end{array}$ \\
\hline SPREAD & $\begin{array}{l}-11.41^{* * *} \\
(2.44)\end{array}$ & $\begin{array}{l}-6.27^{* * *} \\
(2.02)\end{array}$ & $\begin{array}{c}1.20 \\
(2.30)\end{array}$ \\
\hline UPREIT & $\begin{array}{r}0.0018 \\
(0.023) \\
\end{array}$ & $\begin{array}{l}0.042^{*} \\
(0.026)\end{array}$ & - \\
\hline R-squared & 0.62 & 0.61 & 0.53 \\
\hline $\begin{array}{l}\text { F-test p-value: } \alpha_{1}=- \\
\alpha_{2}\end{array}$ & 0.95 & 0.95 & 0.83 \\
\hline
\end{tabular}

* denotes estimated coefficients that are statistically different from zero at the 90 percent confidence level; ${ }^{* *}$ denotes estimated coefficients that statistically different from zero at the 95 percent confidence level; and ${ }^{* * *}$ denotes estimated coefficients that are statistically different from zero at the 99 percent confidence level. All regressions use 393 observations and include a constant and year fixed effects; in Panel A, the regressions include interactions between the year effects and NAV. Standard errors are in parentheses; in the OLS specifications, the standard errors are adjusted for heteroscedasticity from White (1980). In Panel A, dollar figures are in millions of dollars. MVE is the market value of common equity (including the value of OP units in UPREITs), NAV is the net market value of assets, BVA is the book value of real estate properties, which proxies for tax basis in assets, D is the book value of debt, BVPE is the book value of preferred equity, SMALL is a dummy variable equal to one if market capitalization is less than $\$ 400$ million, SPREAD is the average bid-ask spread as a fraction of the midpoint of the bid and ask prices for the month of December, and UPREIT is a dummy variable equal to one if the REIT is an umbrella partnership. The R-squared is defined as the correlation squared between the predicted and actual values of the dependent variable, accounting for the reported variables, the year effects and the year*nav variables (but not the random or fixed effects). 
Table III

Regressions Measuring Tax Basis with Book Value of Common Equity

\begin{tabular}{|c|c|c|c|}
\hline \multicolumn{4}{|c|}{ Panel A: Dependent Variable: MVE } \\
\hline Variable & $\begin{array}{c}\text { (1) } \\
\text { Ordinary Least } \\
\text { Squares }\end{array}$ & $\begin{array}{c}\text { (2) } \\
\text { Random Effects }\end{array}$ & $\begin{array}{l}\text { (3) } \\
\text { Firm Fixed } \\
\text { Effects }\end{array}$ \\
\hline BVCE & $\begin{array}{l}0.15^{* *} \\
(0.068)\end{array}$ & $\begin{array}{l}0.097^{* *} \\
(0.048)\end{array}$ & $\begin{array}{l}0.19^{* * *} \\
(0.068)\end{array}$ \\
\hline $\mathrm{D}$ & $\begin{array}{l}0.18^{* * *} \\
(0.046)\end{array}$ & $\begin{array}{l}0.049^{* *} \\
(0.022)\end{array}$ & $\begin{array}{l}-0.037 \\
(0.030)\end{array}$ \\
\hline BVPE & $\begin{array}{l}0.20^{*} \\
(0.11)\end{array}$ & $\begin{array}{l}-0.033 \\
(0.076)\end{array}$ & $\begin{array}{l}-0.080 \\
(0.086)\end{array}$ \\
\hline SMALL & $\begin{array}{l}-90.3^{* * *} \\
(21.4)\end{array}$ & $\begin{array}{l}-30.6 \\
(26.1)\end{array}$ & $\begin{array}{l}-20.9 \\
(26.8)\end{array}$ \\
\hline SPREAD & $\begin{array}{l}-4690.0 \\
(3300.0)\end{array}$ & $\begin{array}{l}-6320.0^{* * *} \\
(2300.0)\end{array}$ & $\begin{array}{l}-6180.0^{* * *} \\
(2320.0)\end{array}$ \\
\hline UPREIT & $\begin{array}{l}122.0^{* * *} \\
(31.6)\end{array}$ & $\begin{array}{l}183.0^{* * *} \\
(57.7)\end{array}$ & - \\
\hline R-squared & 0.96 & 0.96 & 0.95 \\
\hline
\end{tabular}

Table notes are after Panel B. 


\section{Table III}

\section{Regressions Measuring Tax Basis with Book Value of Common Equity}

\begin{tabular}{|c|c|c|c|}
\hline \multicolumn{4}{|c|}{ Panel B: Dependent Variable: MVE/NAV } \\
\hline Variable & $\begin{array}{c}\text { (1) } \\
\text { Ordinary Least } \\
\text { Squares }\end{array}$ & $\begin{array}{c}\text { (2) } \\
\text { Random Effects }\end{array}$ & $\begin{array}{l}(3) \\
\text { Firm Fixed } \\
\text { Effects }\end{array}$ \\
\hline $\mathrm{BVCE} / \mathrm{NAV}$ & $\begin{array}{l}0.090^{* *} \\
(0.040)\end{array}$ & $\begin{array}{l}0.096^{* *} \\
(0.040)\end{array}$ & $\begin{array}{l}0.20^{* * *} \\
(0.073)\end{array}$ \\
\hline $\mathrm{D} / \mathrm{NAV}$ & $\begin{array}{c}0.0014 \\
(0.027)\end{array}$ & $\begin{array}{l}-0.0024 \\
(0.025)\end{array}$ & $\begin{array}{l}-0.013 \\
(0.033)\end{array}$ \\
\hline BVPE/NAV & $\begin{array}{c}0.092 \\
(0.082)\end{array}$ & $\begin{array}{c}0.043 \\
(0.075)\end{array}$ & $\begin{array}{l}-0.052 \\
(0.087)\end{array}$ \\
\hline SMALL & $\begin{array}{l}-0.11^{* * *} \\
(0.018)\end{array}$ & $\begin{array}{l}-0.12^{* * *} \\
(0.021)\end{array}$ & $\begin{array}{l}-0.097^{* * *} \\
(0.025)\end{array}$ \\
\hline SPREAD & $\begin{array}{l}-11.47^{* * *} \\
(2.45)\end{array}$ & $\begin{array}{l}-6.36^{* * *} \\
(2.02)\end{array}$ & $\begin{array}{c}0.91 \\
(2.30)\end{array}$ \\
\hline UPREIT & $\begin{array}{c}0.0031 \\
(0.023)\end{array}$ & $\begin{array}{l}0.043^{*} \\
(0.026)\end{array}$ & - \\
\hline R-squared & 0.62 & 0.61 & 0.53 \\
\hline
\end{tabular}

${ }^{*}$ denotes estimated coefficients that are statistically different from zero at the 90 percent confidence level; ${ }^{* *}$ denotes estimated coefficients that statistically different from zero at the 95 percent confidence level; and ${ }^{* * *}$ denotes estimated coefficients that are statistically different from zero at the 99 percent confidence level. All regressions use 393 observations and include a constant and year fixed effects; in Panel A, the regressions include interactions between the year effects and NAV. Standard errors are in parentheses; in the OLS specifications, the standard errors are adjusted for heteroscedasticity from White (1980). In Panel A, dollar figures are in millions of dollars. MVE is the market value of common equity (including the value of OP units in UPREITs), NAV is the net market value of assets, BVCE is the book value of common equity, which proxies for tax basis in assets, D is the book value of debt, BVPE is the book value of preferred equity, SMALL is a dummy variable equal to one if market capitalization is less than $\$ 400$ million, SPREAD is the average bid-ask spread as a fraction of the midpoint of the bid and ask prices for the month of December, and UPREIT is a dummy variable equal to one if the REIT is an umbrella partnership. The R-squared is defined as the correlation squared between the predicted and actual values of the dependent variable, accounting for the reported variables, the year effects and the year*nav variables (but not the random or fixed effects). 


\section{Table IV \\ Regressions of Leading FFO \\ on Book Value of Common Equity and NAV}

\begin{tabular}{|l|c|c|}
\hline \multicolumn{1}{|c|}{ Dependent Variable: Future FFO per share (dollars) } \\
\hline \multirow{2}{*}{ Variable } & $\begin{array}{c}(1) \\
\text { Next year's FFO per } \\
\text { share }\end{array}$ & $\begin{array}{c}\text { Sum of FFO per share } \\
\text { for next 3 years }\end{array}$ \\
\hline NAV & $0.090^{* * *}$ & $0.26^{* * *}$ \\
BVCE & $(0.0076)$ & $(0.022)$ \\
& 0.0035 & 0.012 \\
\# of Observations & $(0.0088)$ & $(0.025)$ \\
R-squared & 296 & 159 \\
\hline \hline
\end{tabular}

* $\quad$ Statistically different from zero at the 90 percent confidence level.

** $\quad$ Statistically different from zero at the 95 percent confidence level.

*** $\quad$ Statistically different from zero at the 99 percent confidence level.

The dependent variable is the future funds from operations in either the next year or next 3 years. All FFO numbers are discounted at $7 \%$ per year. The results are essentially the same if we use a higher discount rate of 10 percent or a lower discount rate of 3 percent. Standard errors are in parentheses and reflect the adjustment for heteroscedasticity from White (1980). FFO is funds (i.e., cash flow) from operations, NAV is the net (of liabilities) market value of assets, BVCE is the book value of common equity, which proxies for the tax basis in inside assets. 